JURNAL ILMIAH MANAJEMEN BISNIS DAN INOVASI UNIVERSITAS SAM RATULANGI (JMBI UNSRAT)

\title{
THE EFFECT OF JOB STRESS, JOB SATISFACTION AND ORGANIZATIONAL
} COMMITMENT ON PERFORMANCE

\section{Yanner, Innocentius Bernarto, Dewi Wuisan}

Universitas Pelita Harapan

A R T I C L E I N F O

Keywords: Job Stress, Job Satisfaction, Organizational Commitment,

Performance

Kata Kunci: Stres Kerja, Kepuasan Kerja, Komitmen Organisasi, Performa
Abstract. This study aims to examine the negative effect of job stress on organizati commitment; positive effect of job satisfaction on organizational commitment; neg; job stress on performance; positive effect of job satisfaction on performance; positi organizational commitment on performance. The target population were all $45 \mathrm{JBP}$ teachers. The sampling technique used was saturated or census samples. The data $\mathrm{w}$ through a questionnaire and analyzed using Partial Least Squares - Structural Equat (PLS-SEM) approach using SmartPLS program. The results showed that the job str affected organizational commitment and performance. In addition, the organization: and job satisfaction had a positive effect on performance.

Abstrak. Penelitian ini bertujuan untuk menguji efek negatif dari stres kerja pada komitmen organisasi; pengaruh positif kepuasan kerja terhadap komitmen organisasi; efek negatif dari stres kerja pada kinerja; efek positif kepuasan kerja terhadap kinerja; efek positif dari komitmen organisasi terhadap kinerja. Populasi target adalah semua 45 guru SMA JBP. Teknik pengambilan sampel yang digunakan adalah sampel jenuh atau sensus. Data dikumpulkan melalui kuesioner dan dianalisis menggunakan pendekatan Partial Least Squares - Structural Equation Modeling (PLS-SEM) menggunakan program SmartPLS. Hasil penelitian menunjukkan bahwa stres kerja berpengaruh negatif terhadap komitmen dan kinerja organisasi. Selain itu, komitmen organisasi dan kepuasan kerja berpengaruh positif terhadap kinerja.
Corresponding author:

Innocentius Bernarto bernarto227@gmail.com 


\section{Introduction}

Establishing a school with quality standards is not easy. Each school is required to have a clear curriculum, experienced educators, supporting school facilities and competitive tuition. Meanwhile, more and more new schools are established each year which simultaneously affects parents in choosing a school for their children. To maintain the number of existing students and get more new students, each school formulates strategies and innovates to show their leading characters and uniqueness that are different from other schools. These are done to attract the parents as customers. Over the past three years, the number of students has increased steadily and the school performance is considered excellent as students in JBP High School have good academic and non-academic competencies and are able to compete with students from other schools. Further, educators at JBP High School are experienced, both in the academic and nonacademic fields. They have taken a series of tests, including psychological test, micro teaching, and health test to meet the requirements as teachers of JBP Foundation. All academic and non-academic achievements of JBP High School students are the result of mentoring conducted by the educators who show good quality performance. The implementation of work programs in JBP High School requires the teachers to perform optimally, because it affects the quality of teaching and learning activities and also influences the learning outcomes and the development of students' characters. In addition, a good teacher performance will facilitate the implementation of school activities by achieving targets that are in line with school expectations.

However, in the past year, there had been a change in the patterns of teachers' habits, including the level of timeliness in attending the regular morning briefing where some teachers and employees came late. There were about 3 to 5 teachers who always came late 3 times a week for reasons of getting up late, traffic jam, or being busy taking care of the family in the morning. Most of them were not enthusiastic in listening to the instructions delivered by the school principal or the deputy and instead being busy by themselves, except if they were directly reprimanded. Below, Table 1. displays additional data describing the decline in the teacher performance which was obtained from the HR of JBP Jakarta High School Foundation.

Table 1. JBP High School Teacher Performance

\begin{tabular}{ccccc}
\hline Year & $\begin{array}{l}\text { Total } \\
\text { Number of } \\
\text { Teachers }\end{array}$ & $\begin{array}{l}\text { Number of } \\
\text { Teachers } \\
\text { with } \\
\text { Declining } \\
\text { Performance }\end{array}$ & $\begin{array}{l}\text { Number of Teachers } \\
\text { with Stable } \\
\text { Performance }\end{array}$ & $\begin{array}{l}\text { Number of } \\
\text { Teachers with } \\
\text { Improved } \\
\text { Performance }\end{array}$ \\
\hline $2009-2010$ & 24 & - & 22 & 2 \\
\hline $2010-2011$ & 30 & - & 28 & 2 \\
\hline $2011-2012$ & 34 & 2 & 30 & 2 \\
\hline $2012-2013$ & 37 & 2 & 30 & 3 \\
\hline $2013-2014$ & 39 & 3 & 29 & 3 \\
\hline S014-2015 & 45 & 3 & 39 & 3 \\
\hline
\end{tabular}

Source: JBP High School Teacher Performance Assessment (2016)

Table 1. illustrates that there is an increase in the number of teachers with declining performance each year, varying from $5 \%$ to $7 \%$ or 2 to 3 teachers. This number is considered to be highly influential on the effectiveness of teaching and learning activities, considering that the teaching load of one teacher is 24 hours per week. In addition to the teacher performance data, the following Table 2. shows data on teacher delay: 
Table 2. Data on JBP High School Teacher Delay

\begin{tabular}{cccc} 
Year & $\begin{array}{c}\text { Total } \\
\text { Number of } \\
\text { Teachers }\end{array}$ & $\begin{array}{c}\text { Number of } \\
\text { Teachers } \\
\text { Coming Late }\end{array}$ & $\begin{array}{c}\text { Number of Teachers } \\
\text { Coming On-Time }\end{array}$ \\
\hline $2012-2013$ & 37 & 4 & 33 \\
\hline $2013-2014$ & 39 & 3 & 36 \\
\hline $2014-2015$ & 45 & 8 & 37 \\
\hline
\end{tabular}

Source: Presence data on finger scanner (2016)

Table 2. illustrates that there is an increase in the number of teachers who come late for work each year, varying from $10 \%$ to $20 \%$ or 3 to 8 teachers. The number is considered high. This shows that the teachers' enthusiasm to show their quality performance has gradually decreased, especially in the last two years. Some teachers also complain about their work that could not be completed. They also experience difficulties to complete the tasks well, especially as they have to teach in other schools although it is still within the scope of JBP Jakarta High School Foundation. On one hand, JBP High School always organizes activities such as educational exhibitions, open house, and celebrations that take up the teacher's time so that their routine work disrupted.

This piling up work eventually requires them to work overtime at school, and the situation has an impact on their physical and psychological condition. Feelings of stress with work demands, changing lifestyle patterns such as resting time and irregular eating patterns, and improper time management are complaints that are often expressed by the teachers at JBP High School. A brief interview with one of accounting teachers of 6 years at JBP High School reveals that he felt trapped in an unpleasant work environment with a boss who was too rigid in making decisions. The decisions had always been based on the foundation regulations alone regardless of the policies that could have been agreed at the teacher council meeting as the highest decision maker in the school.

In addition, an interview with an economics teacher of 8 years concludes that he believed that there was a gap between fellow teachers at JBP High School because the decision makers were not such a strong team in making decisions on school policies and regulations. The next short interview was conducted with a mathematics teacher who felt that in the teacher's meeting, the discussion had never focused on the meeting agenda and it was highly difficult to produce firm and clear decisions as the supervisor could not control it.

The last interview was 2 teachers of art and culture. They both objected to the school activities which were always held on Saturday, requiring them to participate although in the work agreement, it was agreed that the honorarium teacher would only attend the school to teach according to their teaching hours, but the boss asked for their commitment to the school. They felt that this was not in accordance with the work agreement. This condition illustrates that the teachers' morale is very weak, they do not enjoy their work, there are excessive workloads given and they are reluctant to contribute more for the school. This can make teachers reluctant to commit to the school and they also work improperly just to fulfill their obligations. Therefore, based on the above explanation, this study aims to examine (1) the negative effect of job stress on teachers' organizational commitment; (2) the positive effect of job satisfaction on teachers' organizational commitment; (3) the negative effect of job stress on teachers' performance; (4) the positive effect of job satisfaction on teachers' performance; and (5) the positive effect of organizational commitment on teachers' performance.

Theoretically, this research contributes to literature, especially on human resources, and also as a reference for conducting future research on the influence of job stress, job satisfaction, and organizational commitment to performance. Practically, the results of this research are expected to encourage teachers to express their opinions and fight for the work rights in the workplace so that there are no deviations in attitudes towards schools and students, to respect and complete assignments given by superiors, and as 
solutions in dealing with stress. In addition, it is also expected that teachers who have stress and dissatisfaction at work, and low organizational commitment can overcome and cope with their problems to improve their performance and simultaneously increase the students' learning quality.

\section{Hypothesis Development}

Relationship between Job Stress and Organizational Commitment

Colquitt (2011) explained that stress is a psychological response to certain demands that exceed the capacity of the person himself. He claimed that the causes of stress are called stressors. Negative consequences as a result of demands exceeding a person's capacity are called strains. Then, Colquitt (2011) argued that the stress also affects not only every individual experiencing it but also the organization. Selye (as cited in Santrock, 2003, p. 560) stated that not all stress is bad. Stress illustrating the positive side is called eustress, for example competing, writing essays and etc. Job stress refers to a person's response to challenges and work pressure that exceeds his capacity which is the interaction of physical and psychological aspects.

Meanwhile, organizational commitment is a belief in values accompanied by a willingness to do their best for the organization's interests as a manifestation of the desire to remain being a member of the organization. Robbins and Judge (2007) added that it is a condition where an employee takes side with a particular organization and his goals and desires are to maintain membership in the organization. A research by Li (2014) revealed that job stress had a negative effect on organizational commitment. Therefore, the first hypothesis that can be proposed in this study is as follows:

\section{$\mathrm{H}_{1}$ : Job stress has a negative effect on organizational commitment}

\section{Relationship between Job Satisfaction and Organizational Commitment}

McShane and Glinow (2009) stated that job satisfaction is a person's assessment of job characteristics, work environment and emotional experience he/she experiences in the workplace. Employees who are satisfied with their work will be happy to evaluate their work and try to make improvements through observation and adjustments to the work environment. In addition, Robbins (2003) defined job satisfaction as a general attitude toward someone's work that shows the difference between the number of rewards received and how much they believe they should receive.

The organizational commitment can also be defined as a belief in values accompanied by a willingness to do their best for the organization's interests as a manifestation of the desire to remain being a member of the organization. Newstorm and Davis (as cited in Kaswan, 2012, p. 293) stated that employees who are committed to the organization usually have a good attendance record, show voluntary loyalty to company policy and have a low turnover rate. Meanwhile, Colquitt (2011) defined it as the desire to be part of an organization. These positive feelings towards work causes a person to further maximize his/her efforts to develop the organization through their work achievement and to maintain his/her trust in the organization through his/her responsibilities and loyalty within the organization. A research by Imam, Raza, and Ahmed (2014) on the impact of job satisfaction on organizational commitment of banking sector employees shows that the job satisfaction had a significant and positive impact on the organizational commitment. Therefore, the second hypothesis that can be proposed in this study is as follows:

\section{$\mathrm{H}_{2}$ : Job satisfaction has a positive effect on organizational commitment}




\section{Relationship between Job Stress and Performance}

Performance refers to a person's behavior in carrying out the tasks and responsibilities given within a certain period of time in accordance with the capabilities and authority possessed and the standards set by the organization. Robbins (as cited in Torang, 2012, p. 121) argued that performance presents functions and abilities, motivation and opportunity. Thus, performance is determined by factors of ability, motivation and opportunity. Further, it is possible that there is an influence between job stress on performance. A research result by Warraich, Ahmed, Ahmad, and Khoso (2014) reveals that the job stress had a negative effect on performance. Therefore, the third hypothesis that can be proposed in this study is as follows:

\section{H3: Job stress has a negative effect on performance}

\section{Relationship between Job Satisfaction and Performance}

Kreitner and Konicki (2005) define job satisfaction as an effectivity or emotional response to various aspects of work. According to Greenberg and Baron (2000), job satisfaction is a positive or negative behavior given by someone to his job. They also added that when employees are dissatisfied with their work, they will look for ways to reduce their involvement in the organization. In other words, they will try to stay away from their work and it is a sign when the employee is distancing from their work. They will usually be absent from work and then decide to resign.

Performance refers to a person's behavior in carrying out the duties and responsibilities given to him in a certain period of time in accordance with the capabilities and authority possessed and the standards set by the organization. Uno and Lamatenggo (2012) stated that there are five dimensions of performance, including work quality, speed or accuracy, initiatives, ability and communication. A person who has a positive attitude towards his/her work will affect his/her work motivation to achieve the highest target as it provides more encouragement to improve performance and achieve good results consistently. Robbins (2003) also suggested that performance cannot be separated from the level of job satisfaction, rewards, skills, willingness and individual traits. Research results by Ahmad, Khursheed, and Shah (2010); Ahmed and Ramzan (2013); Susanty and Miradipta (2013); Wyland. Lester, Ehrhardt, and Standifer (2016) show that job satisfaction was a good predictor of performance. Therefore, the fourth hypothesis that can be proposed in this study is as follows:

\section{$\mathrm{H}_{4}$ : Job satisfaction has a positive effect on performance}

\section{Relationship between Organizational Commitment and Performance}

Mathis and Jackson (as cited in Sopiah, 2008, p. 155) argued that "organizational commitment is the degree to which employees believe in and accept organizational goals and desire to remain in the organization". Thus, organizational commitment is the degree to which employees believe and accept the goals of the organization and will remain and not leave the organization. Cook (2008) defined employee commitment as an individual desire to give their best to the organization in serving consumers. It can also be defined as a belief in values accompanied by a willingness to do their best for the sake of the organization as a manifestation of the desire to remain being a member of the organization. Performance is a person's behavior in carrying out the tasks and responsibilities given to him in a certain period of time based on their capabilities and authority possessed and the standards set by the organization.

Meanwhile, job performance is defined by Colquitt (2011) as the value of a set of employee behavior that contributes (either positive or negative) to the achievement of organizational goals. Wirawan (2015) suggested factors affecting performance, such as: (1) external factors: microeconomic and macroeconomic factors, political condition, socio-cultural life of society, religion / spirituality and competitors; (2) internal factors: organizational culture, organizational climate, and employee factors 
including work ethic, work discipline and job satisfaction. The trust, which is formed in the organizational values and can make a person to commit to his/her work, will make the employee to maximize his/her efforts to provide the best results for the organization. For these reasons, it is possible that there is an influence between organizational commitment and performance. Research results by Ahmad, Khursheed, and Shah (2010); Folorunso, Adewale, and Abodunde (2014); Memari, Mahdieh, and Marnani (2013) show that there was a positive relationship between organizational commitment and employee performance. Therefore, the fifth hypothesis that can be proposed in this study is as follows:

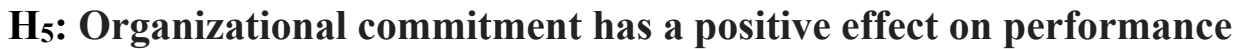

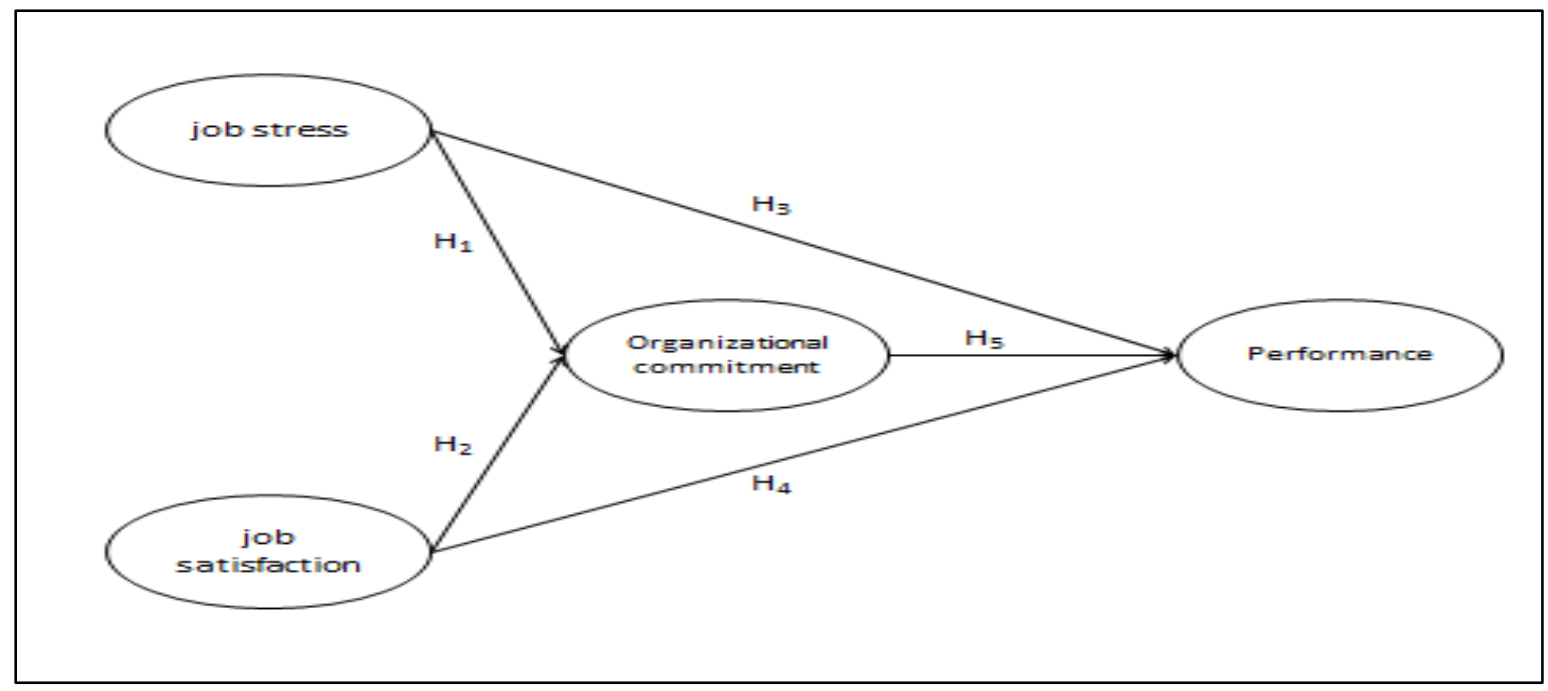

Figure 1. Conceptual Model

\section{Research Methods}

The research method used was a quantitative approach. The data was analyzed using path analysis method. The study was conducted at JBP High School, Tangerang. The research sample was taken by census of all 45 JBP High School teachers. The data was collected using a questionnaire developed based on indicators of each research variable, and measured by a 4-point Likert scale $(1=$ strongly disagree, $2=$ disagree, 3 = agree, and $4=$ strongly agree for the positive statements, and vice versa for the negative statements). The data was analyzed using Partial Least Square-Structural Equation Modeling (PLS-SEM) method of SmartPLS software. There were two important stages taken, including analyzing the measurement model (outer model) and structural model (inner model). The measurement model stage was evaluated through convergent validity, composite reliability, average variance extracted (AVE), and shipment validity, while the structural model was evaluated through R-Square value.

\section{Results and Discussion}

\section{Profile of Respondents}

There were 39 respondents $(87 \%)$ who had worked for $1-9$ years, 5 respondents $(11 \%)$ for $10-19$ years, 1 respondent $(2 \%)$ for 20-29 years and no one $(0 \%)$ for less than $30-39$. Then, there were 4 respondents $(9 \%)$ who had masters' degree, 37 respondents $(82 \%)$ with bachelor degree, no one $(0 \%)$ with diploma, and 4 respondents $(9 \%)$ who were only high school graduates. Next, there were a total of 27 respondents $(60 \%)$ working as permanent employees and the rest 18 respondents (40\%) were nonpermanent employees. In addition, 2 respondents (4\%) were over 25 years old, 39 respondents $(87 \%)$ were 
25-40 years old, and 4 respondents (9\%) were 41-60 years old. Further, there were 27 respondents (60\%) who were married and the rest 18 respondents $(40 \%)$ were not. Most of the respondents $(25$ of them $(56 \%))$ were male and there were only 20 female respondents $(44 \%)$.

\section{Measurement Model}

Examining the validity and reliability of the model was done in the measurement model stage. The validity was measured through loading factors, average variance extracted (AVE), and discriminant validity. The requirements that must be met were that the loading factor values should be greater than 0.7 , and AVE of more than 0.5 . The loading factor value should be between $0.5-0.6$ to be able to be used for analysis and the AVE value should be more than 0.5 (Hair, Hult, Ringle, \& Sarsteedt, 2014). Then, the discriminant validity was based on the Fornel-Larcker criterion where the correlation value between variables should be less than the value of the square root of AVE (Hair et al., 2014). Meanwhile, the reliability test was measured using the composite reliability to examine the instrument reliability. The composite reliability value must be more than 0.7 (Hair et al., 2014).

Table 3. Evaluation of Measurement Model

\begin{tabular}{|c|c|c|}
\hline \multirow{2}{*}{\multicolumn{2}{|c|}{$\begin{array}{l}\text { Variable and item } \\
\text { Job Stress/SK }(\mathbf{A V E}=0.563, \mathbf{C R}=\mathbf{0 . 8 8 4})\end{array}$}} & \multirow{2}{*}{ Outer loading } \\
\hline & & \\
\hline SK1 & I often have headaches while working & 0.657 \\
\hline SK2 & I am not excited because I always think of my work & 0.893 \\
\hline SK3 & I often feel my neck muscles are tense when I am working & 0.762 \\
\hline SK4 & I am vulnerable to illness due to decreased immune system and fatigue at work & 0.666 \\
\hline SK5 & I do not care about people around me at the work I have not finished & 0.786 \\
\hline SK6 & My appetite does not change when I experience stress at work & 0.711 \\
\hline \multicolumn{3}{|c|}{ Job Satisfaction/KK (AVE $=0.559, C R=0.834)$} \\
\hline KK1 & I prioritize work affairs rather than personal affairs & 0.675 \\
\hline KK2 & Co-workers at the school support and help each other & 0.832 \\
\hline KK3 & I feel comfortable working in a team with my colleagues & 0.814 \\
\hline KK4 & I feel that there is almost never a conflict between my co-workers & 0.654 \\
\hline \multicolumn{3}{|c|}{ Organizational Commitment/KO $(\mathrm{AVE}=0.599, \mathrm{CR}=0.882)$} \\
\hline KO1 & I actively provide input to develop the school & 0.817 \\
\hline $\mathrm{KO} 2$ & I do not feel heavy if I have to stop working from this school & 0.753 \\
\hline KO3 & I want to continue working at this school & 0.696 \\
\hline KO4 & I feel that I have a responsibility to develop the school & 0.766 \\
\hline KO5 & I am not willing to be involved in solving the school problems & 0.831 \\
\hline \multicolumn{3}{|c|}{ Performance $/ \mathrm{K}(\mathrm{AVE}=0.554, \mathrm{CR}=0.860)$} \\
\hline $\mathrm{K} 1$ & I create a conducive classroom atmosphere during learning activities & 0.800 \\
\hline $\mathrm{K} 2$ & I regularly make an evaluation after class is finished & 0.809 \\
\hline $\mathrm{K} 3$ & I make a variety of learning media to attract the students' attention & 0.761 \\
\hline \multirow[t]{2}{*}{ K4 } & If there are no teaching aids that I need at school, I try to replace it according to & \\
\hline & my needs $\ldots$ & 0.730 \\
\hline$\underline{\mathrm{K} 5}$ & I always collect information from various sources to update my teaching material & 0.602 \\
\hline
\end{tabular}

Note: $A V E=$ average variance of extracted; $C R=$ composite reliability.

Source: Results of data processing

Table 3. shows that each item has a loading factor that is greater than 0.6 . Thus, each item can be considered valid. Hair et al. (2014) explained that as long as the AVE value was more than 0.5, then the item loading factor could still be used. Furthermore, in Table 1, there are 6 items that have a loading factor value below 0.7 , and 14 other items have values above 0.7 . Then, the composite reliability value for each variable is greater than 0.7 . The composite reliability of job satisfaction, performance, organizational commitment and job stress variable are $0.834,0.860,0.882$, and 0.884 respectively. 
The next validity test was the discriminant validity test. The criteria used were the Fornel-Larcker criteria. Hair et al. (2014) explained that the square root value of AVE must be greater than the correlation value between variables. The following Table 4 . shows the results of discriminant validity.

Table 4. Discriminant Validity Test Results

\begin{tabular}{ccccc}
\hline & $\begin{array}{c}\text { Job } \\
\text { Satisfaction }\end{array}$ & Performance & $\begin{array}{c}\text { Organizational } \\
\text { Commitment }\end{array}$ & $\begin{array}{c}\text { Job } \\
\text { Stress }\end{array}$ \\
\hline Job Satisfaction & 0.748 & & & \\
Performance & 0.297 & 0.744 & & \\
Organizational Commitment & 0.109 & 0.567 & 0.774 & \\
Job Stress & -0.302 & -0.309 & -0.313 & 0.750 \\
\hline
\end{tabular}

Source: Results of data processing

\section{Structural Model}

The data in Table 5. below reveals that the model suitability test could be seen based on the RSquare value. The results conclude that the organizational commitment can be explained by job stress and job satisfaction by $9.8 \%$ and the rest $90.2 \%$ can be explained by other variables not included in the model. While the performance variable is explained by job stress, job satisfaction and organizational commitment by $38.3 \%$ and the rest $61.7 \%$ can be explained by other variables not included in the model.

Table 5. Value of R-square

\begin{tabular}{cc}
\hline Variable & R-Square \\
\hline Performance & 0,383 \\
Organizational Commitment & 0,098 \\
\hline
\end{tabular}

Source: Data processing results

The hypothesis testing did not include the t-test as all members of the population were involved in this study as the respondents. Then, the hypotheses were also directional. Therefore, the hypothesis testing was done by matching the direction of the value of the standardized path coefficient with the hypothesis. If the direction of the standardized path coefficient was positive and the hypothesis was also positive, then the hypothesis could be supported empirically and vice versa. Below, Table 6. shows the results of the hypothesis testing where all of them are supported empirically.

Table 6. Hypothesis Testing Results

\begin{tabular}{lcc}
\hline \multicolumn{1}{c}{ Hypothesis } & Standardized Path Coefficient & $\begin{array}{c}\text { Conclusio } \\
\text { n }\end{array}$ \\
\hline H1: Job stress has a negative effect on organizational commitment & -0.308 & Supported \\
H2: Job satisfaction has a positive effect on organizational commitment & 0.016 & Supported \\
H3: Job stress has a negative effect on performance & -0.082 & Supported \\
H4: Job satisfaction has a positive effect on performance & 0.216 & Supported \\
H5: Organizational commitment has a positive effect on performance & 0.518 & Supported \\
\hline
\end{tabular}

Source: Results of data processing

\section{Discussion}

The results of testing the first hypothesis indicate that the path coefficient value is not equal to zero and is negative at 0.308 . Therefore, the hypothesis stating that the job stress negatively affects organizational commitment is supported empirically. The result is consistent with studies from Li (2014). Thus, the management could increase the organizational commitment by reducing the job stress. They might feel uncomfortable physically which could lead them to have weaker level of health and also simultaneously 
increasing the demand for medical expenses for schools. In addition, when a teacher did not come to work because he/she was sick, the work could be disrupted and make the parties in charge concerned.

The second hypothesis stating that the job satisfaction has a positive effect on organizational commitment is supported empirically. This is indicated by the path coefficient value which is not equal to zero and positive at 0.016. It is supported by a study by Imam, Raza, and Ahmed (2014). Although the effect of job satisfaction on organizational commitment was relatively small, the management must still pay attention to job satisfaction because it could still increase the organizational commitment.

The result of third hypothesis testing shows that the path coefficient value is not equal to zero and equal to -0.082 . Therefore, the hypothesis stating that the job stress negatively influences organizational commitment can be supported empirically. The path coefficient value is negative and shows that when the job stress increased, the performance would decrease. The path coefficient value of 0.082 shows that the job stress was not influential on the performance of teachers at JBP High School. Thus, it can be concluded that although the JBP High School teachers were required to show good performance in carrying out heavy tasks, they were still able to face and complete the challenges of their work well. The results of this study are supported by a research conducted by Warraich et al (2014).

The fourth hypothesis testing results show that the path coefficient value is not equal to zero and equal to 0.216 . Therefore, the hypothesis stating that the job satisfaction has a positive effect on performance can be supported empirically. The path coefficient value is positive and shows that when the job satisfaction increased, the performance would also increase. This indicated that the job satisfaction had an influence on the performance of teachers at JBP High School. Thus, it could be concluded that the work conditions and compensation received by the JBP High School teachers had a positive and significant influence on their work performance. The results of this study are also supported by researchers conducted by Ahmad, Khursheed, and Shah (2010); Ahmed and Ramzan (2013); Susanty and Miradipta (2013); Wyland et al. (2015).

The fifth hypothesis testing results show that the path coefficient value is not equal to zero and equal to 0.518 . Therefore, the hypothesis stating that the organizational commitment has a positive effect on performance can be supported empirically. The path coefficient value is positive and shows that the higher the organizational commitment, the higher the performance would be. The teachers' commitment had the most influence on performance compared to the effect of job satisfaction and stress on their performance. This was indicated by the high path coefficient value of 0.518 . The results of this hypothesis test are supported by researches conducted by Ahmad, Khursheed, and Shah (2010); Folorunso et al. (2014); Memari, Mahdieh, and Marnani (2013).

In addition to discussing the results of the five hypotheses, this study also found that $87 \%$ of respondents were between 25-40 years old, and had completed undergraduate and postgraduate education with work experience of 1-9 years at JBP High School. The data illustrates that the JBP High School teachers were still in productive working age with a high educational background, so that they were expected to have high morale and be able to explore their potential and with learning experiences to develop themselves. Further, the results of this study also explained that $60 \%$ of the respondents were married. According to Dunham, Grube, and Castaneda (1994), employees who were married and had dependents on children would be more committed to the company because marriage demanded increased responsibility. Thus, the married employees wanted a stable job to provide for their family. However, there were $40 \%$ of the respondents with unmarried status. This showed a possibility of a tendency for them not wanting to be burdened with a lot of demands and responsibilities which actually helped them obtaining opportunities to progress and develop, both inside and outside of school. This might bring impacts on their low commitment to JBP High School. 


\section{Limitations and Future Research Suggestions}

The research model did not use intervening variables. Therefore, it could not analyze the effect of the combination of job stress and organizational commitment variable and the combination of job satisfaction and organizational commitment variable on the performance of JBP High School teachers. Future researches are suggested use a model with intervening variables so that it can analyze combination of two variables at the same time. Further, this study also did not analyze the effect of job stress on job satisfaction. Thus, future researches are expected to analyze the effect of job stress on job satisfaction.

In addition, this research was only conducted at the high school level in the JBP Foundation. Future researches can be done at the kindergarten, elementary and junior high levels, both inside and outside the JBP school environment. Furthermore, future researches may involve respondents from public schools to see how much influence the same variables in this study have to make comparisons between the public and private schools.

\section{References}

Ahmad, H., Khursheed, A., \& Shah, I. A. (2010). Relationship between job satisfaction, job performance, attitude towards work, and organizational commitment. European Journal of social Sciences, 18(2), 257-267.

Ahmed, A., \& Ramzan, M. (2013). Effects of job stress on employee job performance a study on banking sector of Pakistan. IOSR Journal of Bisness and Management (IOSR-JBM),11(6), 61-68.

Colquitt, J.A., LePine, J.A., \& Wesson, M.J. (2011). Organizational behavior: Improving performance and commitment in the workplace. New York: McGraw Hill.

Cook, S. (2008). The essential guide to employee engagement: BetterbBusiness performance through. London and Philadelphia: Kogan Page, Ltd.

Dunham, R. B., Grube, J.A., \& Castaneda, M. B. (1994). Organizational commitment: The utility of an integrative definition. Journal of Applied Psychology, 79(3), 370 - 380.

Folorunso, O.O., Adewale, A. J., \& Abodunde, S.M. (2014). Exploring the effect of organizational commitment dimensions on employees performance: An empirical evidence from academic staff of Oyo State owned tertiary institution, Nigeria, International Journal of Academic Research in Business and Social Sciences. 4(8), 275-286.

Greenberg, J., \& Baron, R.A. (2000). Behavior in organization, $7^{\text {th }}$ Ed. USA: Prentice - Hall, Inc.

Hair, J. F., Hult, G. T. M., Ringle, C.M., \& Sarsteedt, M. (2014). A primer on partial least squares structural equation modleing (pls-sem). Los Angeles: SAGE.

Imam, A., Raza, A., \& Ahmed, M. (2014). Impact of job satisfaction on organizational commitment in banking sector employees of Pakistan, Sci. Int (Lahore), 26 (1), 419-423.

Kaswan, (2012). Manajemen SDM untuk keunggulan bersaing organisasi. Yogyakarta: GRAHA ILMU.

Kreitner, R., \& Konicki, A. (2005). Perilaku organisasi. Jakarta: Salemba Empat. 
Li, Y. (2014). Building affective commitment to organization among Chinese university teachers: The roles of organization justice and job burnout. Edu Asse Eval Acc., 26, 135-152, (2014).

McShanne, S., \& Glinow, V.(2009). Organizational behavior (2 ${ }^{\text {nd }}$ Ed). New York: McGraw Hill, Inc.

Memari, N., Mahdieh, O., \& Marnani, A. B. (2013). The Impact of organization commitment on employees job performance "A Study of Meli Bank. Institute of interdisciplinary Businees Research, 5(5), 164171.

Robbins, S. P. (2003). Perilaku organisasi : Konsep, kontroversi, dan aplikasi. Edisi Bahasa Indonesia. Jakarta: Prehalindo.

Robbins, S.P., \& Judge, T. A. (2007). Organizational behavior (12th ed.). Upper Saddle River, N.J.: Pearson Prentie Hall.

Santrock, J.W. (2003). Adolescence : Perkembangan remaja. Jakarta: Penerbit Erlangga.

Sopiah, (2008). Perilaku organisasional. Yogyakarta: ANDI.

Susanty, A., \& Miradipta, R. (2013). Employee's job performances: The effect of attitude toward works, organizational commitment, and job satisfaction. Jurnal Teknik Industri, 15(1), 13-24.

Torang, S. (2012). Metode riset struktur dan perilaku organisasi. Bandung: Alfabeta.

Uno, H., \& Lamatenggo, N. (2012). Teori kinerja dan pengukurannya. Jakarta: PT. Bumi Aksara.

Tulung, J. E. (2010). Global Determinants of Entry Mode Choice. Journal of Indonesian Economy and Business, 25(2), 155-169.

Tulung, J. E. (2017). Resource Availability and Firm's International Strategy as Key Determinants Of Entry Mode Choice. Jurnal Aplikasi Manajemen, 15(1), 160-168.

Warraich, U. A., Ahmed, R., Ahmad, N., \& Khoso, I. (2014). Impact of stress on job performance: An empirical study of employees of private sector Universities of Karachi, Pakistan. Research Journal of Management Sciences, 3(7), 14-17.

Wirawan., (2015). Manajemen sumber daya manusia Indonesia. Jakarta: RajaGrafindo Persada.

Wyland, R.,Lester, S. W., Ehrhardt, K., \& Standifer, R. (2016). An examination of the relationship between the work-school interface, job satisfaction, and job performance. J Bus Psychol, 31, 187-203. 